\title{
PROFIL TNF- $\alpha$ PADA ORANG LANJUT USIA DI PANTI WREDHA BETHANIA LEMBEAN
}

\author{
${ }^{1}$ Aristo R. Lumentut \\ ${ }^{2}$ Sylvia Marunduh \\ ${ }^{3}$ J. J. V. Rampengan
}

\begin{abstract}
${ }^{1}$ Kandidat Skripsi Fakultas Kedokteran Universitas Sam Ratulangi Manado
${ }^{2}$ Bagian Fisiologi Fakultas Kedokteran Universitas Sam Ratulangi Manado

Email: aristolumentut@yahoo.com
\end{abstract}

\begin{abstract}
TNF- $\alpha$ is a pleiotrophic cytokine that plays an important role in the inflammatory system, especially in an acute inflammation. This cytokine initiates and activates polymorphonuclears (PMNs) to reach the site of infection. This was an observational study with a pre-test design. This study aimed to obtain the TNF- $\alpha$ level among elderly. Population was all elderly in Bethania nursing home in Lembean. Subjects were 30 people obtained by using simple random sampling. The TNF- $\alpha$ level was measured by using sandwich ELISA technique with a kit of Quantikine ELISA Human TNF- $\alpha$, R\&D, USA. The results showed that the average level of TNF- $\alpha$ in subjects aged $64-74$ years $(73.33 \%)$ was $78.63 \mathrm{pg} / \mathrm{ml}$. Seven subjects aged 75-90 years (23.33\%) had the average level of TNF- $\alpha 69.56 \mathrm{pg} / \mathrm{ml}$; and 1 subject aged >90 years (3.33\%) with the TNF- $\alpha$ level $133.05 \mathrm{pg} / \mathrm{ml}$. Conclusion: Most of the elderly in Bethania nursing home in Lembean had normal TNF- $\alpha$ level, however, some of them had increased TNF- $\alpha$ level.
\end{abstract}

Keywords: TNF $\alpha$, elderly

\begin{abstract}
Abstrak: TNF- $\alpha$ adalah suatu sitokin pleiotropik yang berperan dalam sistem inflamasi, yang menginisiasi polymorphonuclear (PMN) dan mengaktivitasinya sehingga PMN dapat mencapai tempat infeksi. Peran TNF- $\alpha$ khususnya pada inflamasi akut. Penelitian ini bersifat observasional dengan rancangan pre-test design. Penelitian ini bertujuan untuk mendapatkan kadar TNF- $\alpha$ pada orang lanjut usia. Populasi ialah semua lanjut usia di wilayah kerja Panti Wredha Bethania Lembean. Subyek penelitian berjumlah 30 orang yang diambil dari populasi secara simple random sampling. Pengukuran kadar TNF- $\alpha$ menggunakan teknik Sandwich ELISA dengan kit Quantikine ELISA Human TNF- $\alpha$, R\&D, USA. Hasil penelitian memperlihatkan 22 subyek berumur 64-74 tahun (73,33\%) dengan rerata kadar TNF- $\alpha$ 78,63 $\mathrm{pg} / \mathrm{ml}$; 7 subyek berumur 75-90 tahun (23,33\%) dengan rerata kadar TNF- $\alpha 69.56 \mathrm{pg} / \mathrm{ml}$; dan 1 subyek berumur $>90$ tahun (3,33\%) dengan kadar TNF- $\alpha 133.05 \mathrm{pg} / \mathrm{ml}$. Simpulan: Sebagian besar orang usia lanjut di Panti Wredha Bethania Lembean mempunyai kadar TNF- $\alpha$ berada pada kisaran normal. Kadar TNF- $\alpha$ yang meningkat ditemukan pada sebagian kecil subyek.
\end{abstract}

Kata kunci: TNF $\alpha$, lanjut usia

Keberhasilan Pemerintah dalam harapan hidup manusia. Akibatnya jumlah Pembangunan Nasional telah mewujudkan penduduk yang berusia lanjut meningkat hasil yang positif di berbagai bidang, terutama di bidang kesehatan, sehingga dapat meningkatkan kualitas kesehatan penduduk serta meningkatkan umur dan bertambah cenderung lebih cepat. Hal ini dapat dilihat menurut sensus penduduk pada tahun 1980 di Indonesia jumlah penduduk 147,3 juta. Dari angka tersebut 
terdapat 16,3 juta orang (11\%) yang berusia 50 tahun ke atas, dan 6,3 juta orang $(4,3 \%)$ berusia 60 tahun ke atas serta dari 6,3 juta orang terdapat $822.831(13,06 \%)$ orang tergolong jompo, yaitu para usia lanjut yang memerlukan bantuan khusus. ${ }^{1}$

Secara alamiah, perjalanan penyakit berkembang secara lambat dan gejalagejalanya tidak terlihat sampai beberapa tahun kemudian. Pada orang tua produksi imunoglobulin yang dihasilkan oleh tubuh juga berkurang. Selain itu, tubuh orang tua kehilangan kemampuan untuk membedakan benda asing yang masuk ke dalam tubuh ataupun bahan yang merupakan bagian dari tubuhnya sendiri (penyakit autoimun). ${ }^{2}$

Reaksi imunologis merupakan mekanisme yang berkaitan dengan pertahanan inang terhadap suatu antigen seluler atau non-seluler. ${ }^{3}$ Dewasa ini berbagai macam sitokin telah dilaporkan dan menjadi lahan penelitian yang sangat diminati. Berbagai macam interaksi antarsitokin yang telah dikenal, yaitu: 1) sinergistik atau antagonistik; 2) induksi atau inhibisi; dan 3) regulasi ekspresi reseptor. ${ }^{4}$ Abbas (1994) menyatakan bahwa fungsi sitokin dapat disebutkan dalam beberapa kategori, yaitu: sebagai mediator imunitas bawaan, mengatur aktivasi, pertumbuhan dan diferensiasi sel limfosit, mengatur immune mediated inflammation, merangsang leukosit yang imatur dalam pertumbuhan dan diferensiasi. Theze (1999) menyatakan bahwa fungsi dasar sitokin yang diproduksi akibat adanya respon terhadap rangsangan yang bersifat imunologik, berperan utama dalam kelanjutan hidup sel, proliferasi sel, diferensiasi sel dan kematian sel. ${ }^{5}$

Salah satu jenis sitokin yaitu tumor necrosis factor alpha (TNF- $\alpha$ ) pertama kali ditemukan pada tahun 1975 oleh Craswell et al. yang mengidentifikasinya pada sarkoma. TNF- $\alpha$ merupakan suatu sitokin pleiotropik yang berperan dalam sistem inflamasi, yang menginisiasi polymorphonuclear (PMN) dan mengaktivitasinya sehingga PMN dapat mencapai tempat infeksi. Peran TNF- $\alpha$ khususnya pada inflamasi akut. ${ }^{6}$

TNF terutama dihasilkan oleh sel makrofag dan sel-sel jenis lainnya dengan berbagai aktivitas biologi pada sel-sel sasaran yang termasuk sistem imun maupun bukan. Sejumlah jenis sel baru dapat menghasilkan TNF setelah mendapatkan rangsangan yang sesuai misalnya dari limfosit dan sel NK. Sumber TNF- $\alpha$ plasma pada keadaan aterosklerosis belum jelas, dapat berasal dari makrofag maupun sel lainnya seperti sel endotel dan sel lemak. Sangat menarik terungkapnya jejaring pengawasan induksi dan efek dari TNF, misalnya IL-1 menginduksi produksi TNF dan sebaliknya TNF menginduksi produksi IL-1 oleh makrofag, produksi IFN- $\beta 1$ dan IFN- $\beta 2$ oleh fibroblas dan produksi GM-CSF oleh berbagai jenis sel. ${ }^{7}$

Terdapat 2 bentuk TNF, yaitu TNF- $\alpha$ dan TNF- $\beta$. TNF- $\alpha$ diproduksi oleh berbagai jenis sel termasuk makrofag, sel limfosit T, B, dan NK, astrosit, serta sel Kupffer akibat adanya suatu stresor ataupun infeksi. Akhir-akhir ini terungkap TNF- $\alpha$ juga TNF- $\beta$ sebagai limfotoksin karena mempunyai efek sitotoksik, dan dihasilkan oleh limfosit TH1, sebagian oleh limfosit TH2 dan sel T sitotoksik. TNF- $\beta$ disekresi oleh sel limfosit $\mathrm{T}$ dan sel $\mathrm{T}$ teraktivasi. $^{7}$

Penuaan berhubungan dengan renovasi kompleks dan konstan dari fungsi kekebalan tubuh sehingga orang tua menjadi lebih rentan terhadap penyakit infeksi dan lain-lain. Infeksi yang disebabkan oleh mikroorganisme Gram negatif sering dijumpai di panti jompo dan rumah sakit, dan salah satu penyakit yang umumnya ditemukan pada orang tua ialah adanya sel-sel imun bawaan. Pada orang tua, monosit memroduksi basal TNF- $\alpha$ dan MCP-1 yang lebih tinggi dan TGF- $\beta$ yang lebih rendah. ${ }^{8}$

Pada usia lanjut penyakit yang sering dijumpai ialah hipertensi yang disertai gangguan mikrovaskuler. Sitokin proinflamasi mempunyai implikasi pada cedera serebrovaskuler, terutama oleh karena aterosklerosis dan hipertensi. Salah satu penelitian melaporkan bahwa 54 dari 
70 penderita yang diteliti terdapat peningkatan IL-6 dan TNF- $\alpha .^{9}$

\section{METODE PENELITIAN}

Penelitian ini bersifat observasional dengan rancangan pre-test design. Penelitian ini dilaksanakan di Panti Wredha Lembean dari bulan November 2014 Januari 2015. Populasi ialah semua lansia di wilayah kerja Panti Wredha Lembean. Subyek penelitian berjumlah 30 orang yang diambil dari populasi secara Simple Random Sampling. Pengukuran kadar TNF$\alpha$ menggunakan teknik sandwich ELISA dengan menggunakan kit Quantikine ELISA Human TNF- $\alpha$, R\&D, USA.

\section{HASIL PENELITIAN}

Tabel 1. Distribusi subyek berdasarkan kelompok umur

\begin{tabular}{cccc}
\hline $\begin{array}{c}\text { Umur } \\
\text { (tahun) }\end{array}$ & $\mathrm{N}$ & $\%$ & $\begin{array}{c}\text { Rerata TNF- } \alpha \\
\mathrm{pg} / \mathrm{ml}\end{array}$ \\
\hline $64-74$ & 22 & 73,33 & 78,63 \\
$75-90$ & 7 & 23,33 & 69,56 \\
$>90$ & 1 & 3,33 & 133,05 \\
Jumlah & 30 & 100 & \\
\hline
\end{tabular}

Tabel 2. Distribusi subyek berdasarkan jenis kelamin

\begin{tabular}{cccc}
\hline $\begin{array}{c}\text { Jenis } \\
\text { Kelamin }\end{array}$ & $\mathrm{N}$ & $\%$ & $\begin{array}{c}\text { Rerata TNF- } \alpha \\
\mathrm{pg} / \mathrm{ml}\end{array}$ \\
\hline Laki-laki & 13 & 43,33 & 98.22 \\
\cline { 3 - 4 } Perempuan & 17 & 56,67 & 62,04 \\
\hline Jumlah & 30 & 100 & \\
\hline
\end{tabular}

Tabel 3. Distribusi subjek berdasarkan kadar TNF- $\alpha$ pada lansia

\begin{tabular}{lcc}
\hline TNF- $\alpha$ pg/ml & N & $\%$ \\
\hline$<10$ & 0 & 0 \\
$10-100$ & 26 & 86,67 \\
$>100$ & 4 & 13,33 \\
\hline Jumlah & 30 & 100 \\
\hline
\end{tabular}

\section{BAHASAN}

Berdasarkan hasil observasi yang dilakukan maka didapatkan data TNF- $\alpha$ pada sejumlah orang lanjut usia di panti Wredha Bethania Lembean, yaitu sebagian besar kadar TNF- $\alpha$ masih dalam keadaan normal dan terdapat 4 orang dengan kadar TNF- $\alpha$ di atas normal.

Pada penelitian ini, subyek yang berumur 64-74 tahun (73,33\%) memiliki rerata kadar TNF- $\alpha$ 78,63 pg/ml. Subyek yang berumur 75-90 tahun (23,33\%) memiliki rerata kadar TNF- $\alpha$ 69,56 pg/ml, sementara subyek berumur $>90$ tahun berjumlah 1 orang (3,33\%) dengan kadar TNF- $\alpha$ 133,05 pg/ml. Menurut teori yang dikemukakan oleh Grounds MD, menyatakan bahwa produksi hormon dan sitokin yang optimal mengalami penurunan seiring dengan pertambahan usia, secara jelas faktor- faktor intrinsik yang lain pada otot rangka meliputi perubahan matriks ekstrasel, peredaran darah dan faktor pertumbuhan khususnya reseptor dari sel dapat menyebabkan penurunan efisiensi dari regenerasi pada usia tua dan biasanya atrofi otot terjadi pada umur 60 tahun ke atas. ${ }^{10}$ Hasil penelitian ini kurang sesuai dengan yang dikemukakan oleh Grounds MD.

Berdasarkan jenis kelamin diketahui subyek yang memiliki jenis kelamin lakilaki sebanyak 13 orang (36,33\%) dengan rerata kadar TNF- $\alpha$ 98,22 pg/ml sedangkan subyek yang memiliki jenis kelamin perempuan sebanyak 17 orang (63,33\%) dengan rerata kadar TNF- $\alpha 62,04 \mathrm{pg} / \mathrm{ml}$. Dari hasil yang ditemukan dapat dilihat terdapat perbedaan kadar TNF- $\alpha$ pada kedua jenis kelamin, dengan hasil kadar TNF- $\alpha$ laki laki lebih tinggi dari pada perempuan.

Berdasarkan distribusi Tabel 3, hasil permeriksaan kadar TNF- $\alpha$, diketahui subyek yang memiliki kadar TNF- $\alpha 10-100$ $\mathrm{pg} / \mathrm{ml}$ sebanyak 26 orang (86,67\%); subyek yang memiliki kadar TNF- $\alpha>100 \mathrm{pg} / \mathrm{ml}$ sebanyak 4 orang (13,33\%); dan tidak ditemukan subyek yang memiliki kadar TNF- $\alpha<10 \mathrm{pg} / \mathrm{ml}$. Pada 21 orang yang memliki kadar TNF- $\alpha$ 10-100 pg/ml masih termasuk dalam batas normal, sedangkan sampel yang memiliki kadar TNF- $\alpha>100$ pg/ml, telah melewati batas normal. Kadar TNF- $\alpha$ yang berlebihan dapat memicu gejala sistemik organ seperti proses radang. 
Pada olahraga singkat dengan beban berlebihan kadar TNF- $\alpha$ dapat meningkat lebih dari batas normal.

\section{SIMPULAN}

Berdasarkan hasil di Panti Wredha Bethania Lembean dapat disimpulkan bahwa sebagian besar orang usia lanjut mempunyai kadar TNF- $\alpha$ berada pada kisaran normal. Kadar TNF- $\alpha$ yang meningkat ditemukan pada sebagian kecil subyek.

\section{DAFTAR PUSTAKA}

1. SP Kantor Menpora Nomor: B/0227/K/MENPORA/84. Jakarta, 13 Februari 1984.

2. Fatmah. Respons imunitas yang rendah pada tubuh manusia usia lanjut. Makara, Kesehatan. 2006; 10(1):4753.

3. Ishartadiati K. Peranan TNF, IL-1, dan IL-6 pada respon imun terhadap protozoa. Surabaya: Universitas Wijaya kusuma, 2010.

4. Soeroso A. Sitokin. Jurnal Oftalmologi Indonesia. 2007;5:171-80.
5. Theze J. The Cytokine Network and Immune Functions. New York: Oxford University Press, 1999.

6. Baeyens. TNF- $\alpha$. National Center of Biotechnology Information, 2008.

7. Made IM. Pemberian growth hormone menurunkan kadar tumor necrosis factor- $\alpha$ (TNF- $\alpha)$ pada tikus jantan yang dislipidemia [Tesis]. Denpasar: Program Pascasarjana Universitas Udayana, 2011.

8. Pinke KH, Calzavara B, Faria PF, do Nascimento MPP, Venturini J, Lara VS. Proinflammatory profile of in vitro monocytes in the ageing is affected by lymphocytes presence. Immunity \& Ageing. 2013;10:22.

9. Zuhir E. Hubungan gangguan fungsi kognitif dengan hipertens ditinjau dari aspek il-6 dan TNF- $\alpha$ lfa [Tesis]. Padang: program Pascasarjana Univeristas Andalas, 2011.

10. Grounds MD. reasons for the degeneration of ageing skeletal muscle: a central role for IGF-1 signaling. Biogerontology. 2002;3:19-24. 